\title{
Hi-Tech - Determinants Restricting Competencies of Managers
}

\author{
Gabriela Roszyk-Kowalska \\ Poznań University of Economics and Business, Poland \\ g.roszyk-kowalska@ue.poznan.pl
}

Received date: 14 September 2021; Accepted date: 3 February 2021; Published date: 4 June 2021

Academic Editor: Justyna Śpiewak

Copyright (C) 2021. Gabriela Roszyk-Kowalska. Distributed under Creative Commons Attribution 4.0 International CC-BY 4.0

\begin{abstract}
Management competence is of significant importance in the Hi-Tech sector. The relevance of the issue led the author of the article to undertake research to identify and assess the determinants limiting the improvement of managerial competencies in Hi-Tech organisations. Factors impeding the furtherance of managers' competencies include those within the organisation itself and those located in its environment. From the many conclusions that have been drawn from the results of the research investigation, one may point out the following relationships:

- For managerial staff of the strategic level, the most important determinants influencing changes in managerial competences should include an increase in formal requirements for jobs and the consumption rate (propensity to consume);

- For managerial staff of the tactical and operational level, according to the ratings, the most important determinants are mobility and expenditure on R\&D in Poland and the share of R\&D expenditure in Hi-Tech industries.
\end{abstract}

The final part of the study suggests ways to overcome barriers in the process of improving the competences of managers operating in the analysed economic sector.

Keywords: Hi-Tech organizations, managerial competences, competences

\section{Introduction}

Undertaking activities aimed at identifying and assessing determinants restricting the improvement of managerial competences in Hi-Tech organizations, a critical analysis of literature on the subject was performed, which enabled the systematization of dispersed knowledge on managerial competences. Filling the theoretical 
cognitive gap, an attempt was made to clarify this ambiguous concept, because so far, no coherent definition of 'competence' that would be adopted by all theorists has been introduced. On the basis of a critical analysis of literature on the subject, it was found that the concept of competence is understood as the totality of knowledge, experience, skills and attitudes, where: (1) knowledge is the content preserved in the memory of a person in a managerial position, which results from the learning process, (2) experience [Thomas and Cheese, 2005, pp. 24-29] is the totality of knowledge and skills acquired on the basis of observations and own experiences of a person holding the position of a manager, (3) skills constitute a manager's ability to function efficiently in an organization, and (4) attitudes are beliefs and behaviours towards someone or something. Theoretical considerations allowed for the formulation of a conclusion that individual elements of competences are interrelated, and it is difficult to indicate their clear divisibility. However, such attempts were made because key competences of managers in $\mathrm{Hi}$-Tech organizations were proposed using the method of source critique and logical analysis, interview technique, questionnaire technique, the method of competent judges, comparative analyses and statistical tests of measuring relationships between variables. These competences were related to the characteristics of $\mathrm{Hi}$-Tech organizations due to the positively assessed role of this sector in stimulating socio-economic development [Roszyk-Kowalska and Kraśniak, 2020, p. 38].

Managerial competences were selected on the basis of an analysis of literature on the subject and with the involvement of experts from the area subjected to empirical research. It was found that managerial competences differ depending on the industry [Tiruneh, Fayek, 2019, p. $3]$, the specificity of the managerial work or the requirements set for a manager. Therefore, in economic practice it is postulated to construct key competences, i.e. those that all people in managerial positions need in order to satisfy the needs of self-realization and being active in an organization, for which they should constitute capital.

Key competences of managerial staff in HiTech organizations include entrepreneurship, creativity, knowledge management, teamwork, innovation, cooperation in relational systems, employee empowerment, R\&D activity management, basing communication systems on modern IT technologies according to the level of education (supplemented with additional qualifications), seniority, key skills and key attitudes [Roszyk-Kowalska, 2018, pp. 1922].

In the process of acquiring competences, knowledge, experience, skills and professional attitudes complement each other, but this does not mean that they are of the same importance.

The course of the managerial work process is influenced by specific situational determinants called, inter alia, conditions, determinants, and indicators of the efficiency of managerial work in the process of managing an organization. These determinants condition the manager's achievement of the efficiency of his/her work [Kraśniak and Roszyk-Kowalska, 2019, p. 54].

As a result of the conducted research, the determinants existing both in the environment of Hi-Tech organizations and within them, restricting the improvement of key competences of management staff in Hi-Tech organizations, were demonstrated.

\section{Research Procedure}

Based on the analysis of literature on the subject and observation of the economic practice of $\mathrm{Hi}$-Tech organizations, a conclusion was formulated that the determinants of change that exist both in the environment and in an organization, itself are sources of limitations in the improvement of managerial competences. Therefore, a pilot study (2019) was carried out among managerial staff of all levels, asking them to indicate (open-ended questions) elements of the political and 
legal, economic, technological, sociocultural, international and internal environment of an organization that had an impact on their changes in attitude and/or skills and/or experience and/or education. After listing a specific determinant from a given environment, managerial staff was also asked to specify the time period when this change took place. The purpose of such a procedure was not only to identify the determinants that, according to managerial staff, influenced their changes in competences, but also to "make" respondents think about this determinant from the point of view of the criterion of time. Fifty-six people took part in the research, of which thirteen people were from a strategic management level, thirty people from a tactical management level and thirteen people from an operational management level (random selection).

Then, all the determinants identified in individual areas of the political and legal, economic, technological, socio-cultural, international and internal environment of an organization, using the method of competent judges, were aggregated and flattened in each group to the six most important ones from the perspective of the research problem.

For this purpose, eighteen experts were appointed, including representatives of economic universities. The deliberate selection of competent experts was guided by the principle of specialization, hence, people with significant scientific achievements (scientific publications in a given field) were invited to participate in the research.

Electronic means were used to communicate with the experts. Each of the experts received a list with the determinants indicated by respondents in a given area (in line with the scientific achievements) and was asked to aggregate and flatten the number of determinants, considered by the expert to be the most important, to six.

After receiving the material from the experts, research questionnaires, which were used during the actual surveys, were developed. In this research procedure, senior management was asked to distribute ten points among no more than five statements, depending on the extent to which they believe a determinant, in their environment, has influenced (or influences) changes in attitude and/or skills and/or experience and/or education of people employed in the enterprise where they work at the tactical and/or operational level. In contrast, managerial staff of the tactical and operational level was asked to distribute ten points between no more than five statements, depending on the extent to which a given determinant has influenced (or influences) changes in their attitude and/or skills and/or experience and/or education (selfassessment).

After the completion of the research procedure, information was obtained on the determinants of the external and internal environment of an organization from 504 people.

The indicators of importance of individual determinants were determined as the average indication for managerial staff of an appropriate level and given as a percentage of the maximum possible indication. For example, a value of 10 for the determinant "frequent changes of the government" means that managerial staff of the strategic level gave this determinant $10 \%$ of their points (Fig 1). Firstly, such a transformation allowed to compare the ratings of managerial staff of the strategic level with the ratings of lower-level managerial staff, despite significant differences in the size of the two groups, and secondly, it illustrated the differentiation of ratings of individual determinants, maintaining appropriate relationships.

\section{Results of the Research Procedure}

The analysis of the received ratings shows that for managerial staff of the strategic level, the most important determinant is an increase in formal requirements for jobs. Instability of law follows in the second place, though it is clearly less important. The remaining determinants obtained 
significantly lower values. On the other hand, for managerial staff of the operational and technical level, the most important determinants are integration with the European Union and an increase in formal requirements for jobs, while other determinants: instability of law and frequent changes of the government received only slightly lower ratings. The ratings of lower-level managerial staff are distributed more evenly, the importance is given to several determinants, while the ratings given by managerial staff of the strategic level focus on one or two determinants.

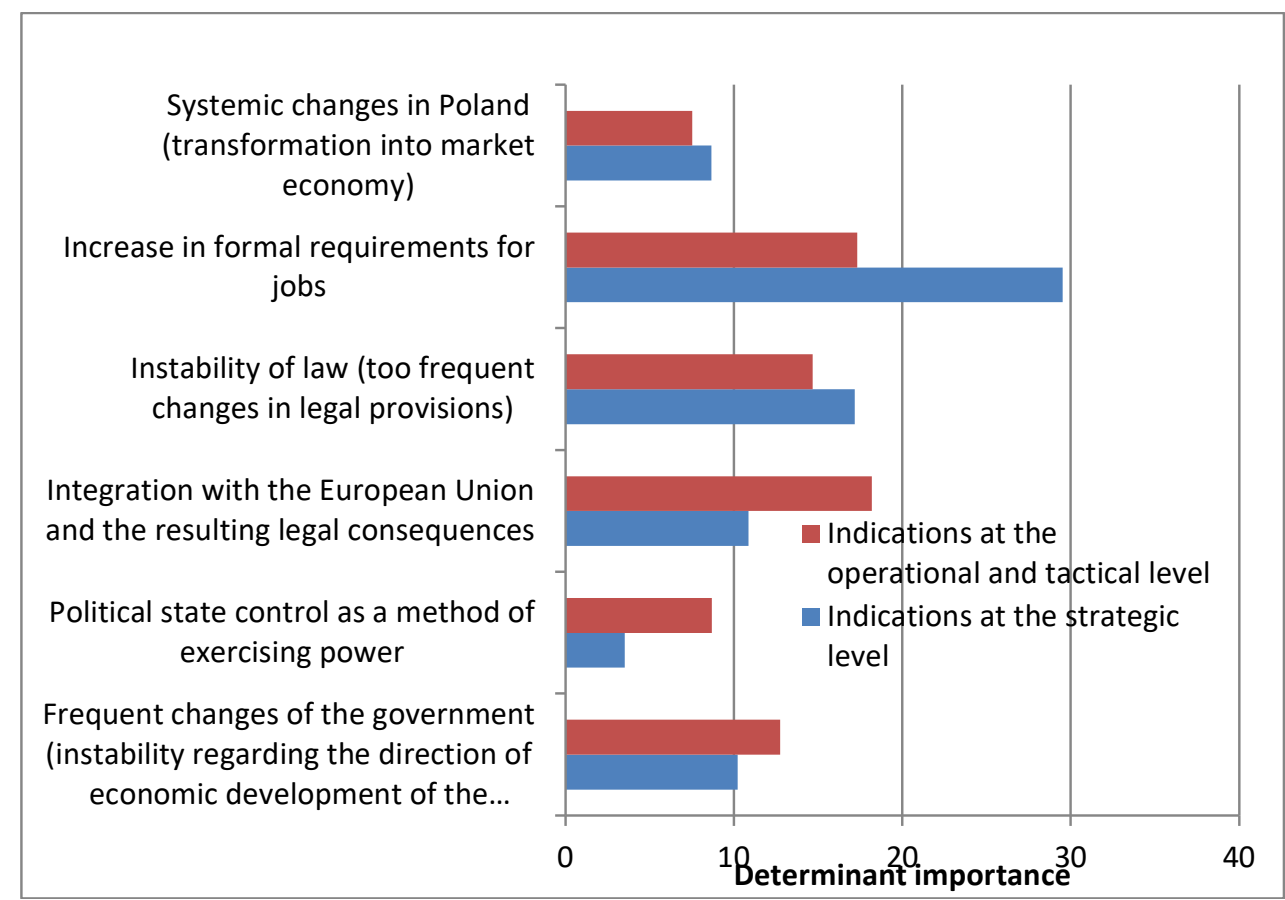

Fig .1: The importance of determinants from the political and legal environment for managerial staff of $\mathrm{Hi}$-Tech organizations

Source: own elaboration.

In order to assess the convergence of the ratings of the importance of determinants, the following correlation coefficients were calculated: Spearman's rank - due to the small number of determinants (six in each group) and additionally, Pearson's linear correlation. The rank correlation coefficient examines the sequence dependence, so it takes into account only the order of the determinants, while it ignores the size of the difference between the indications of subsequent determinants. The difference between the determinant "an increase in formal requirements for jobs" that received 30\% of importance and "instability of law" with $17 \%$ of importance is treated, in the rank correlation coefficient, in the same way as the difference between "frequent changes of the government" $(10 \%)$ and "systemic changes in Poland" (9\%). Pearson's linear correlation coefficient is sensitive to these differences and is therefore used here. Due to the small number of observations, it can only be treated as a supplement to the rank correlation coefficient. 
Table 1: Correlation between the indications of managerial staff of the strategic level and managerial staff of the tactical and operational level in Hi-Tech organizations in the area of determinants from the political and legal environment

\begin{tabular}{|l|r|r|}
\hline & \multicolumn{1}{|c|}{$\begin{array}{c}\text { Correlation } \\
\text { coefficient }\end{array}$} & Value $\boldsymbol{p}$ \\
\hline Spearman's rank & 0.77 & 0.0724 \\
\hline Pearson's linear & 0.66 & 0.1499 \\
\hline
\end{tabular}

Source: own elaboration.

The value of the coefficients indicates the existence of an average relationship in the sample, which means that the indications are moderately convergent. However, this relationship is not statistically significant at the significance level of 0.05 (Spearman's correlation coefficient is significant at the significance level of 0.1 ).

Therefore, it should be recognized that in the area of determinants from the political and legal environment, the most important determinant influencing decisions on the improvement of key competences of managerial staff in $\mathrm{Hi}$-Tech organizations is an increase in formal requirements for jobs, and then instability of law (too frequent changes in legal regulations). On the other hand, for managerial staff of the tactical and operational level, the first determinant influencing actions taken in the process of improving key competences of managerial staff in Hi-Tech organizations is integration with the European Union and the resulting legal consequences, followed by an increase in formal requirements for jobs and instability of law (too frequent changes of legal provisions) in the third position.

On the other hand, analysing the determinants of the economic environment (Fig 2), it was shown that for managerial staff of the strategic level, the consumption rate (propensity to consume) is the most important, followed by the unemployment rate and the rate of economic growth and return on capital in improving key competences of managerial staff in $\mathrm{Hi}$-Tech organizations. On the other hand, for managerial staff of the tactical and operational level, the unemployment rate is the most important, followed by the consumption rate (propensity to consume) and exchange rates. 


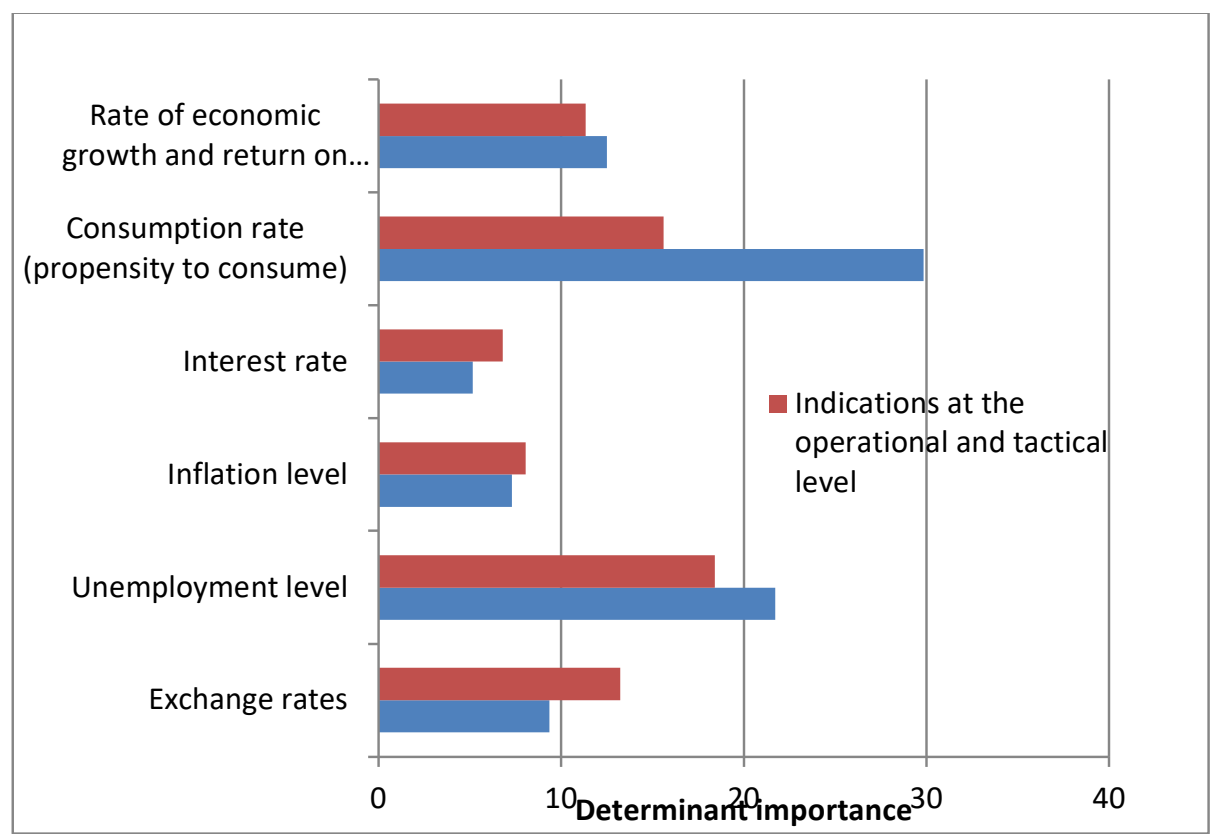

Fig. 2: The importance of determinants from the economic environment for managerial Source: own elaboration. staff of Hi-Tech organizations

Table 2: Correlation between the indications of managerial staff of the strategic level and managerial staff of the tactical and operational level in Hi-Tech organizations in the area of determinants from the economic environment

\begin{tabular}{|l|r|r|}
\hline & \multicolumn{1}{|c|}{$\begin{array}{c}\text { Correlation } \\
\text { coefficient }\end{array}$} & Value $\boldsymbol{p}$ \\
\hline Spearman's rank & 0,89 & 0.0188 \\
\hline Pearson's linear & 0,82 & 0.0453 \\
\hline
\end{tabular}

Source: own elaboration.

A positive, quite strong relationship has been shown, which means that the opinions of managerial staff of the strategic, tactical and operational level are similar. It is a statistically significant relationship (at the significance level of 0.05).

Then, analysing the determinants of the technological environment (Fig 3), it has been shown that for managerial staff of the strategic level, the most important determinant is the development of new technologies in Poland, followed by expenditure on $R \& D$ in Poland and the share of expenditure on R\&D in Hi-Tech industries and access to new technologies in improving key competences of managerial staff in $\mathrm{Hi}$-Tech organizations. On the other hand, for managerial staff of the tactical and operational level, expenditures on R\&D in Poland and the share of $R \& D$ expenditures in $\mathrm{Hi}$-Tech industries are most important, followed by access to new technologies and the development of new technologies in Poland. 


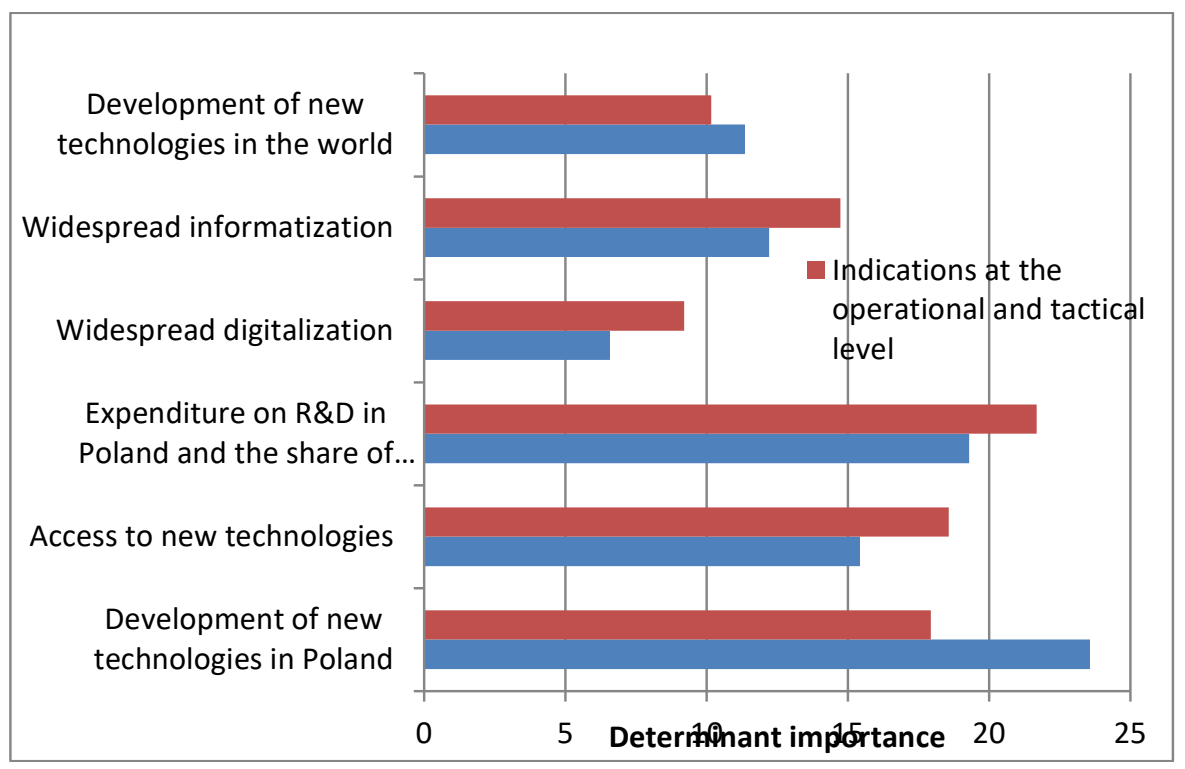

Fig.3: The importance of determinants from the technological environment for managerial staff of Hi-Tech organizations

Source: own elaboration.

Table 3: Correlation between the indications of managerial staff of the strategic level and managerial staff of the tactical and operational level in Hi-Tech organizations in the area of determinants from the technological environment

\begin{tabular}{|l|r|r|}
\hline & \multicolumn{2}{|c|}{$\begin{array}{l}\text { Correlation } \\
\text { coefficients }\end{array}$} \\
\hline Spearman's rank & 0.83 & Value $\boldsymbol{p}$ \\
\hline Pearson's linear & 0.0416 \\
\hline
\end{tabular}

Source: own elaboration.

A positive, quite strong relationship has been shown, which means that the opinions of managerial staff of the strategic, tactical and operational level are similar. It is a statistically significant relationship (at the significance level of 0.05).

Subsequently, the determinants from the socio-cultural environment were analysed. In the group of these determinants, mobility was the most indicated one by senior management, followed by the demand for innovative products and changes in the social structure. Therefore, it can be concluded that these determinants constitute an important source of information in the implementation of the process of improving key competences of managerial staff in Hi-Tech organizations. Meanwhile, for managerial staff working in these organizations, the determinants of changes in key competences are: mobility, the demand for innovative products and globalization processes (Fig 4). 


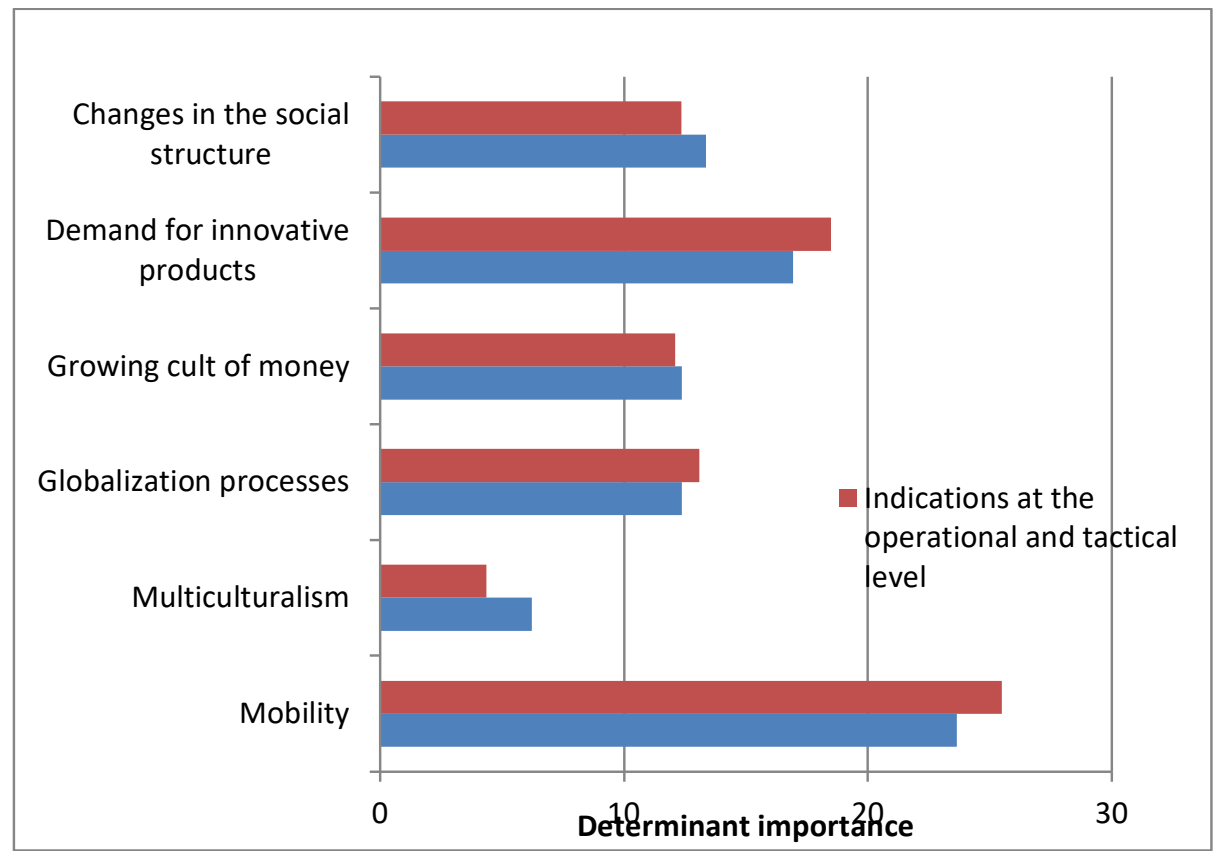

Fig. 4: The importance of determinants from the socio-cultural environment for managerial staff of $\mathrm{Hi}$-Tech organizations

Source: own elaboration.

Table 4: Correlation between the indications of managerial staff of the strategic level and managerial staff of the tactical and operational level in Hi-Tech organizations in the area of determinants from the socio-cultural environment

\begin{tabular}{|l|r|r|}
\hline & \multicolumn{1}{|c|}{$\begin{array}{c}\text { Correlation } \\
\text { coefficient }\end{array}$} & Value $\boldsymbol{p}$ \\
\hline Spearman's rank & 0.87 & 0.0237 \\
\hline Pearson's linear & 0.99 & 0.0000 \\
\hline
\end{tabular}

Source: own elaboration.

In this case, the relationship is very strong and positive. This means the convergence of indications made by managerial staff of all management levels. The relationship is statistically significant (at the significance level of 0.05).

Moving on to the analysis of the last group of determinants from the organization's environment, it was shown that among the determinants from the international environment (Fig 5), the highest rated determinants in the opinion of managerial staff of the strategic level include trips, contacts abroad, and the complexity and speed of changes taking place on the international market. Both these determinants received the highest percentage of ratings. A slightly lower percentage $(13 \%)$ was achieved by the following determinants: institutional solutions adopted in other countries, economic competition, and removal of legal barriers. On the other hand, for tactical and operational level managers, three determinants $(15 \%)$ are rated identically: global changes in the area of generational differences, meeting(s) with (a) new business partner(s) from abroad, and trips and contacts abroad. 


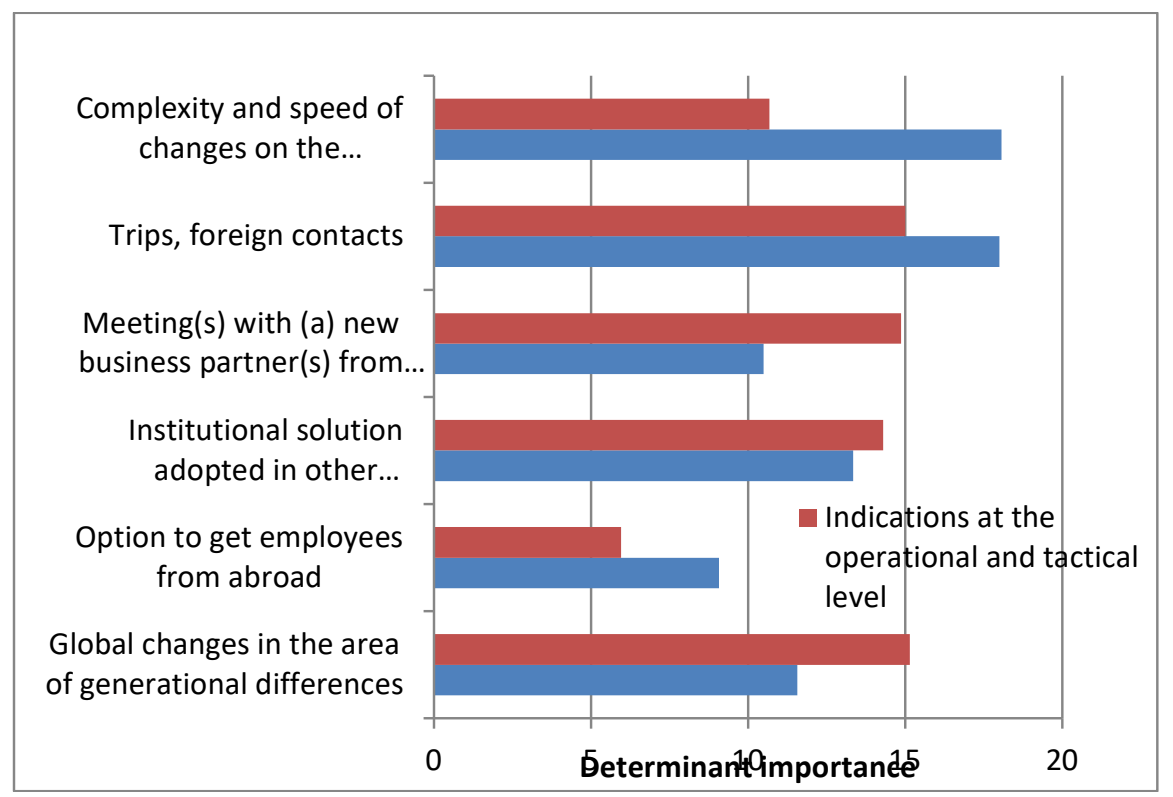

Fig. 5: The importance of determinants from the international environment for managerial staff of $\mathrm{Hi}$-Tech organizations

Source: own elaboration.

Table 5: Correlation between the indications of managerial staff of the strategic level and the tactical and operational level in Hi-Tech organizations in the area of determinants from the international environment

\begin{tabular}{|c|c|c|}
\hline & $\begin{array}{c}\text { Correlation } \\
\text { coefficient }\end{array}$ & Value $p$ \\
\hline Spearman's & 0.24 & 0.6429 \\
\hline Pearson's linear & 0.28 & 0.5952 \\
\hline
\end{tabular}

Source: own elaboration.

Indications of senior managerial staff, middle management and managerial staff of the lowest level do not coincide. Correlation coefficients indicate an insignificant relationship (at the significance level of 0.05 ). This indicates that the opinions of managerial staff as to the determinants from the international environment that may affect the process of improving key competences of managerial staff in Hi-Tech organizations are divergent. Therefore, it can be assumed that the motives for action in this area may differ as to the motivation for taking action in this area, depending on the groups of managerial staff.
Significant determinants, influencing activities of any organization, are those that are inherent in themselves. The group of determinants coming from inside the organization include those which, according to literature on the subject, directly affect the functioning of a given enterprise. These are the determinants with the greatest potential to influence it from the point of view of people operating in a given organization. Among the internal determinants of an organization, the most important (24\%), in the opinion of managerial staff of the strategic level, are the educational offer and the development of the organization. Changes in the financial condition of an organization constitute a slightly lower rated but quite important 
determinant. On the other hand, for managerial staff of the tactical and operational level, the determinants that may affect the process of improving key competences of managerial staff in Hi-Tech organizations are: educational offer in a given organization, changes in the financial condition of a given organization and change of job position (Fig 6).

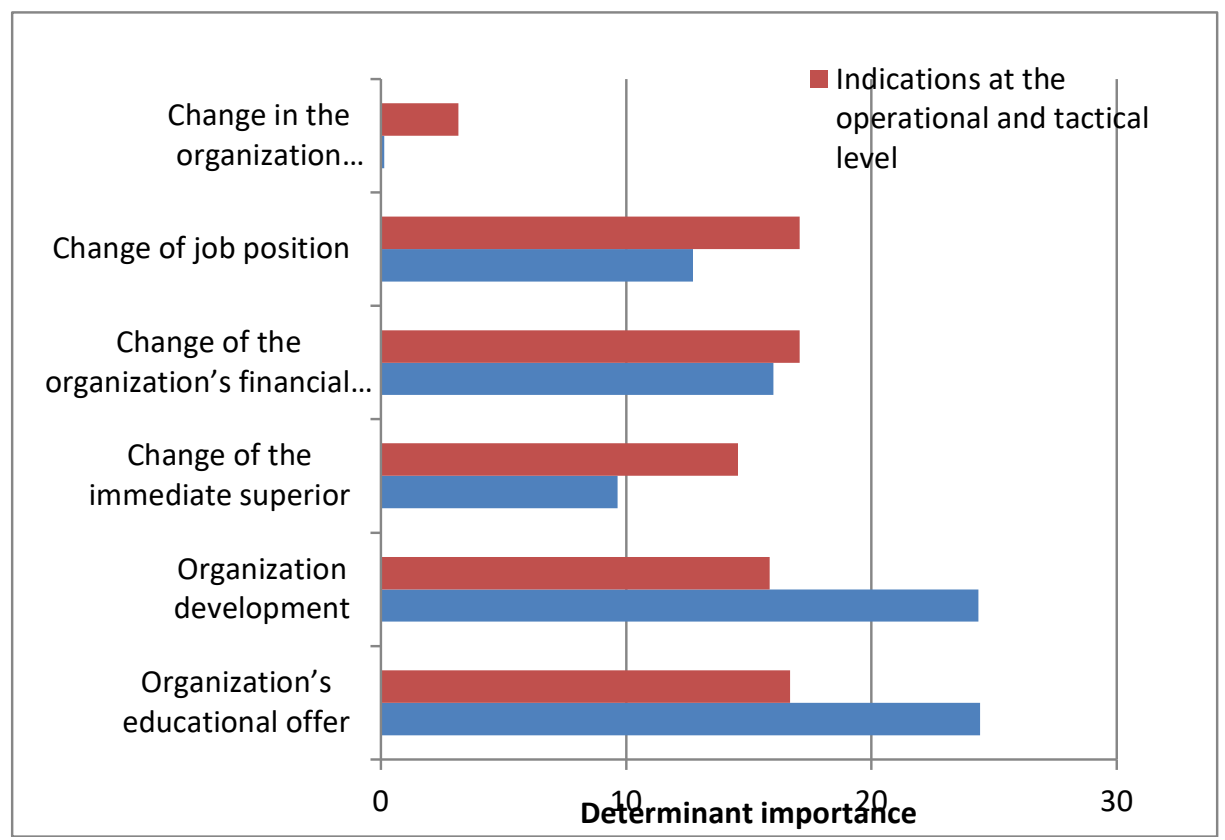

Fig. 6: The importance of internal determinants for managerial staff of Hi-Tech organizations

Source: own elaboration.

Table 6: Correlation between the indications of managerial staff of the strategic level and the managerial staff of the tactical and operational level in Hi-Tech organizations in the area of intra-organizational determinants

\begin{tabular}{|c|c|c|}
\hline & $\begin{array}{c}\text { Correlation } \\
\text { coefficient }\end{array}$ & Value $p$ \\
\hline Spearman's rank & 0.67 & 0.1442 \\
\hline Pearson's linear & 0.78 & 0.0667 \\
\hline
\end{tabular}

Source: own elaboration.

Indications obtained in the research are moderately similar. The correlation coefficients show a moderate correlation. However, this correlation is statistically insignificant (at the significance level of 0.05).

\section{Conclusions}

It should be acknowledged that in individual groups of determinants from the environment of a given organization (political and legal, economic, technological, socio-cultural, international) and internal determinants, in the research process, differences were identified regarding the importance of individual determinants for managerial staff at the strategic level and managerial staff at the tactical and operational level. The largest statistical discrepancy occurs among the determinants inherent in the international environment, then the political and legal environment, and in $\mathrm{Hi}$-Tech organizations themselves. Such a situation may lead to the conclusion that managerial staff may 
have different priorities in making decisions within their competences, both in the area of education, additional qualifications, experience, skills and attitudes. Therefore, it is postulated to attempt to overcome these barriers, which may be of significant importance in the improvement of key competences of managerial staff in Hi-Tech organizations. Therefore, the following actions should be undertaken:

- Clearly and precisely defining competencies (the list of competencies of managerial staff may be used to identify competency gaps [Tyrańska, 2016, p. 21]) and avoid any ambiguities in this respect,

- Structuring the competency model to make it as easy to use as possible,

- Being aware that appropriate quality standards must be applied in the development of key managerial competences.

These quality standards should assume that the structure of the process of improving key managerial competences should:

- Be transparent and generally understandable,

- Be suitable for an appropriate application to all personnel for which it is designed,

- Take anticipated changes into account,

- Be characterized by a clear separation and divisibility of components (skills and attitudes cannot overlap),

- Be fair and not cause unjustified discrimination against any of the persons within its reach.

Only when employees of a given organization are aware of the purpose of the process of improving key managerial competences, and when the structure of the process itself corresponds to the abovementioned quality standards, it is possible to proceed with its implementation [Whiddett and Hollyforte, 2003, p. 209].
Therefore, the following actions should be undertaken:

- Involve employees who will be affected by the actions of managerial staff in the formation of the process of improving key managerial competences;

- During the formation of the process of improving key managerial competences, inform employees about what actions are taken and why, on an ongoing basis;

- Make sure that the process of improving key managerial competences is adequate to the planned applications and goals, and that the competences reflect the specificity of individual positions and roles [Whiddetti Hollyforte, 2003, p. 210].

The choice of a method or methods of improvement should depend not only on the competence to be improved, but also on the individual learning style of a given person [Musioł-Urbańczyk, 2010, p. 75].

Unfortunately, there are no shortcuts in improving key managerial competences. This process requires constant analysis, observation and formulation of conclusions. Nevertheless, there are many methods that can help any manager with this, and each has its pros and cons. In order to develop competences (especially in the short term), trainings, workshops, and courses can be used. It is postulated to choose those in which activating methods are used, such as role-playing, recording scenes with a video camera, behaviour analysis, coach's feedback, and working on specific problems. This form of education does not guarantee that managers will completely master a given skill, or change their attitude, because the development of these elements of competences also requires practice, i.e. hands-on training. However, it can be a good start on their career path. The undoubted advantage of trainings, workshops, and courses is that managers receive knowledge in a given area in a nutshell, often supported by reallife examples. It is also a great opportunity 
to make new friends among participants, which, in itself, means developing relationship building skills.

It is also postulated to "nurture" the organizational culture, which in $\mathrm{Hi}-\mathrm{Tech}$ organizations (from the point of view of their characteristics), should be flexibilityoriented, and therefore, its attributes should include passion, power-sharing and continuity of change.

\section{Ending}

The analysis of the research procedure results shows that for managerial staff of the strategic level, the most important determinants influencing changes in managerial competences should include an increase in formal requirements for jobs and the consumption rate (propensity to consume). The slightly lower rated but important determinants should include the development of new technologies in Poland, the development of a given organization and the educational offer in Hi-Tech organizations. On the other hand, for managerial staff of the tactical and operational level, the above-mentioned determinants are important, but according to the ratings, the most important determinants are mobility and expenditure on R\&D in Poland and the share of R\&D expenditure in Hi-Tech industries. It is also worth emphasizing that the importance of the determinants "change of job position" and/or "change of the immediate superior" is higher than in the ratings of managerial staff of the strategic level. The importance of determinants influencing changes in managerial competencies according to managerial staff of the strategic level in comparison to managerial staff of the tactical and operational level varies, is a reason for the conclusion that managerial staff, depending on the management level, may have different priorities in making decisions regarding changes in their competences both in the area of knowledge, experience skills and attitudes. Therefore, an attempt was made to propose methods to overcome barriers in the process of improving key competences of managerial staff in Hi-Tech organizations.
In conclusion, it should be emphasized that not a single person is fully competent. In such a situation, first of all, it is necessary to perform tasks related to key competences very well and to follow certain rules, which can be called the principles of competent management. This is the minimum to be expected and required of a manager. Violation of this minimum is not only a violation of managerial duties, but also of universal ethical principles. Someone who does not want or is unable to meet this managerial minimum should not occupy a managerial position [Kietliński, Reyes and Oleksyn 2005 , p. 197]. It is also worth remembering that the development of competencies is a process that should be continued throughout the entire period of holding a given position in a given company.

\section{References}

- Kraśniak, J., Roszyk-Kowalska, G. (2019), Kompetencyjne uwarunkowania wdrażania struktury procesowej [Competencerelatedconditions for the implementation of the processstructure], Wydawnictwo Naukowe SILVA RERUM, Poznań.

- Musioł-Urbańczyk, A. (2010), Kompetencje kierownika projektu $i$ możliwości ich kształtowania [Project manager'scompetences and the possibility of shapingthem], Wydawnictwo Politechniki Śląskiej, Gliwice.

- Roszyk-Kowalska, G., Kraśniak, J. (2020), Kluczowe kompetencje kadry kierowniczej przedsiębiorstw sektora Hi-Tech. Diagnozalukiumiejętności [Key competences of managerial staff of companies in the high technology sector. Skill Gap Diagnosis], Przegląd Organizacji, no 4 (963).

- Roszyk-Kowalska, G. (2018), Kompetencje kadry kierowniczej w przedsiębiorstwach wysokich technologii [Competences of managerialstaff in high technology enterprises], Wydawnictwo Uniwersytetu Ekonomicznego w Poznaniu, Poznań. 
- Thomas, R.J., Cheese, P. (2005), Leadership: Experience is the Best Teacher, Strategy \& Leadership, vol. 33, no 3.

- Tiruneh, G.G., Fayek, A.R. Competency and Performance Measures for Organizations in the Construction Industry, Canadian Journal of Civil Engineering, Received December 04, 2019, https://doi.org/10.1139/cjce2019-0769

- Tyrańska, M. (2016), Managerial Competencies for Various Management
Levels, Cracow Review of Economics and Management, no 11(959).

- Whiddett, S., Hollyforte, S. (2003), Modele kompetencyjne $w$ zarządzaniu zasobami ludzkimi [Competencerelatedmodels in humanresource management], Oficyna Ekonomiczna, Kraków. 